\title{
Identifikasi Infeksi Ektoparasit pada Ikan Mas (Cyprinus carpio L.) di Perairan Waduk Darma, Kabupaten Kuningan Provinsi Jawa Barat
} \author{
Reservoir at Kuningan districts of West Java Province] \\ Yuke Eliyani $^{凶}$ \\ Sekolah Tinggi Perikanan, Jurusan Penyuluhan \\ Perikanan Jalan Cikaret Nomor 1 Bogor 16001, \\ Jawa Barat \\ Diterima: 1 Agustus 2017; Disetujui: 27 \\ Agusutus 2017
}

[Identification of ectoparasit infection in carp (Cyprinus carpio L.) in Darma

\begin{abstract}
Abstrak
Penelitian ini bertujuan untuk mengidentifikasi serangan infeksi ektoparasit pada ikan mas (Cyprinus carpio) yang perairan Waduk Darma Kabupaten Kuningan, Provinsi Jawa Barat, pada bulan Agustus 2017. Identifikasi dan analisa ektoparasit dilaksanakan di Laboratorium Kesehatan Ikan, Departemen Akuakultur, Institut Pertanian Bogor. Hasil identifikasi menunjukkan terdapat tiga jenis parasit yang memiliki nilai prevalensi yang sama yaitu sebesar 66,67: Trichodina sp., Epistylis sp., serta Gyrodactylus sp.Nilai prevalensi tertinggi dicapai oleh parasit Dactylogyrus sp, namun dominansi parasit $(7,53)$ ini tidak mencapai nilai tertinggi. Adapun nilai dominansi dan intensitas tertinggi diperoleh parasit Epistylis sp. dengan nilai sebesar 69,49 dan 715,40 . Terdapat hasil yang menarik dari penelitian ini, dimana lima jenis parasit dari total 10 parasit yang ditemukan adalah dari golongan Monogenea (Cichlidogyrus sp., Gyrodactylus sp., Heterobothrium sp., Diplozoon sp., serta Dactylogyrus sp.).
\end{abstract}

Kata Kunci: Cyprinus carpio, Dominansi, Ektoparasit, Identifikasi,Prevalensi

\begin{abstract}
The aim of this study was to identify ectoparasite infection in goldfish (Cyprinus carpio) maintained in floating net of Darma Reservoir of Kuningan Regency, West Java Province, in August 2017. Ectoparasite identification and analysis was conducted at Fish Health Laboratory, Department of Aquaculture, Bogor Agricultural University . The identification results show that there are three types of parasites that have the same prevalence value of 66.67: Trichodina sp., Epistylis sp., And Gyrodactylus sp. The highest prevalence value is achieved by Dactylogyrus sp parasite, but the dominance of this parasite (7.53) is not reaching the highest score. The highest dominance and intensity value obtained by parasite Epistylis sp. with a value of 69.49 and 715.40. There are interesting results from this study, where five types of parasites from a total of 10 parasites are found from Monogenea (Cichlidogyrus sp., Gyrodactylus sp., Heterobothrium sp., Diplozoon sp., And Dactylogyrus sp.) Groups.
\end{abstract}

Keywords: Identification, Ectoparasites, Cyprinus carpio, Prevalence, Dominance

$\triangle$ Penulis korespondensi

Alamat surel: yukeeliyani@yahoo.co.id 


\section{PENDAHULUAN}

Waduk Darma merupakan salah satu waduk buatan yang juga terletak di bagian hulu daerah aliran $\mathrm{Ci}$ Sanggarung dibawah pengelolaan Balai Pengelolaan Sumberdaya Air (PSDA) Ci Manuk, Ci Sanggarung, Ci Tanduy.

Lokasi waduk terletak di areal wilayah administrasi Kabupaten Kuningan, Provinsi Jawa Barat Waduk Darma dibangun tahun 1962, dengan daya tampung maksimal \pm 40 juta meter kubik. Debit air sebanyak itu, dapat menyuplai ke areal persawahan seluas 22.060 ha di sembilan daerah pengairan di Kabupaten Kuningan dan Kabupaten Cirebon. Rata-rata debit air yang dikeluarkan adalah $100-300$ 1t/dt (Ismail $d k k, 2015)$.

Pengelolaan Waduk Darma agak berbeda dengan waduk-waduk lainnya yang berada di Provinsi Jawa Barat, yang memanfaatkan areal perairan untuk kegiatan budidaya ikan di jaring apung. Walaupun ada beberapa pembudidaya yang memelihara ikan, namun tidak dalam kawasan khusus, sehingga dapat dikatakan bahwa di waduk ini, tidak ada kegiatan budidaya ikan secara komersial dalam luasan yang besar. Jenis ikan yang dibudidayakan diantaranya adalah ikan Mas. Kondisi kesehatan ikan yang dibudidayakan di kawasan ini menarik untuk diamati, sebagai bahan kajian dan perbandingan dengan kawasan waduk lainnya.

Metoda budidaya ikan mas pada jaring apung di Waduk Darma relatif sama dengan lokasi lain, diantaranya pemanfaatan ruang perairan dengan menggunakan padat tebar tinggi serta penggunaan pakan buatan selama masa pemeliharaan ikan. Kondisi ini secara langsung menyebabkan adanya interaksi antara lingkungan, ikan serta keberadaan patogen yang akan mempengaruhi baik tingkat pertumbuhan ikan dan maupun produktivitas hasil ikan budidaya yang dilakukan dalam satu siklus produksi. Salah satu agen patogen yang menarik untuk dicermati adalah keberadaan ektoparasit.

Secara umum ektoparasit di Waduk Darma diduga relatif sama dengan ektoparasit di waduk lokasi budidaya lainnya, misal dari genus Monogenea yang cenderung akan menginfeksi insang. Ektoparasit jenis ini akan sangat merugikan biota yang akan diserangnya karena akan menimbulkan kerusakan baik terhadap 
filamen maupun juga terhadap lamella insang, sehingga penyerapan oksigen akan terganggu.

Pengamatan jenis ektoparsait di areal Waduk Darma serta analisanya, diharapkan dapat juga memberikan kontribusi dalam hal kesehatan ikan, yang dapat menjadi salah satu masukan bagi para pembudidaya ikan di lokasi tersebut. Keberadaan ektoparsit ini, apabila dicermati dari awal pemeliharaan ikan, setidaknya akan dapat mengurangik rugian yang diduga berkemungkinan menimbulkan masalah pada tingkat kesehatan ikan.

Penelitian ini bertujuan untuk dapat mengidentifikasi adanya suatu serangan infeksi ektoparasit pada ikan mas (Cyprinus carpio) yang terdapat perairan Waduk Darma, pada bulan Agustus 2017.

\section{BAHAN DAN METODE}

Penelitian ini dilaksanakan pada bulan Agustus tahun 2017 di perairan Waduk Darma Kabupaten Kuningan. Pemeriksaan ektoparasit dilaksanakan di Laboratorium Kesehatan Ikan lingkup Departemen Akuakultur pada Institut Pertanian Bogor. Analisa sampel kualitas air dilaksanakan dilakukan secara in situ. Lokasi penelitian di Waduk Darma

Kabupaten Kuningan, dapat dilihat pada Gambar 1.

Populasi penelitian ini adalah ikan hasil tangkapan pada titik tertentu di setiap waduk yang menjadi lokasi penelitian. Jumlah total sampel ikan yang diperiksa sebanyak 15 ekor/waduk. Rancangan penelitian ini merupakan penelitian eksplorasi dengan metode survei. Survei lapangan di lakukan langsung di Waduk Darma yang menjadi lokasi penelitian.

$$
\text { Pengamatan langsung }
$$
kondisi ikan sampel serta adanya gejala ikan sakit dan ikan yang mati sebagai data pendukung. Pengambilan sampel ikan dilakukan bersamaan dengan kegiatan pengambilan sampel air untuk parameter kualitas air. 


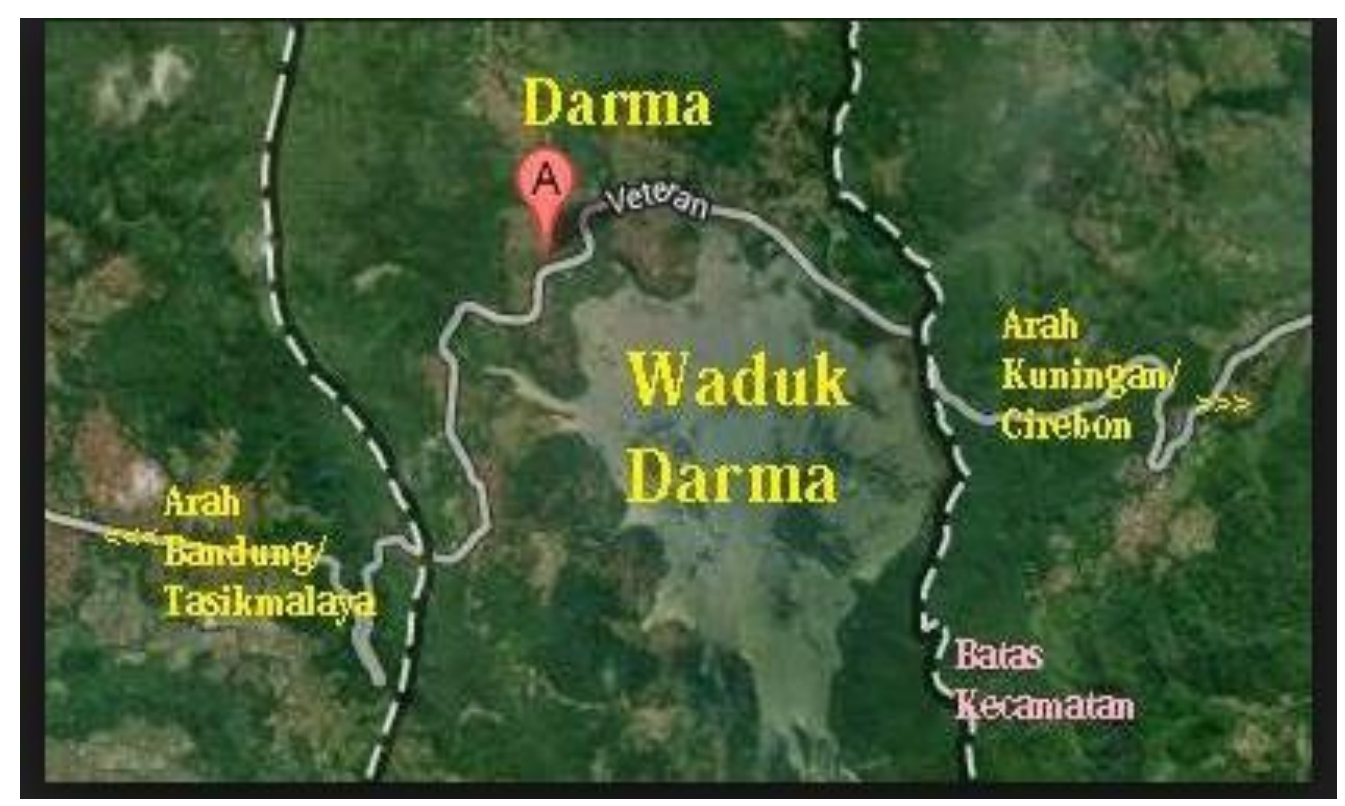

Gambar 1. Lokasi penelitian di areal perairan Waduk Darma Kabupaten Kuningan

Peralatan yang digunakan dalam penelitian ini adalah object glass, cover glass, alat bedah/dissecting kit (gunting, pisau bedah, pinset ujung runcing, scalpel), pipet tetes, ember, nampan plastik, termometer, penggaris, alat tulis, kamera, dan juga mikroskop binokuler. Sedangkan bahan penelitian adalah: Ikan sampel, akuades, alkohol $70 \%$, test kit (DO, $\mathrm{NH}_{3}, \mathrm{pH}$,), oksigen murni dalam tabung, plastik packing, karet gelang, kertas label. Pengambilan sampel dilakukan satu kali pada Bulan Agustus 2017. Sampel diambil langsung dari komoditas ikan mas yang tertangkap di perairan Waduk Darma dan dimasukkan ke dalam kantong plastik yang telah diberi air dan oksigen dengan jumlah sampel sebanyak 15 ekor; kemudian di bawa ke Laboratorium Kesehatan Ikan, Departemen Akuakultur, pada Institut Pertanian Bogor untuk pemeriksaan parasit. Pengambilan data pendukung penelitian pada tahap ini antara lain kualitas air yaitu suhu air waduk, $\mathrm{pH}$, Oksigen terlarut, dan Amonia.

Pelaksanaan penelitian diawali dengan pengambilanlendir, insang serta siripdengan cara mengerok bagian kulit ikan, sisik, kepala sampai ekor menggunakan scalpel hingga

mendapatkan lendir (cairan muсus). Kemudian lendir diletakkan di atas 
object glass ditetesi akuades, ditutup dengan cover glass, diamati di bawah mikroskop.Pemeriksaan ektoparasit pada bagian insang dilakukan dengan cara memotong bagian insang menggunakan gunting kemudian diletakan pada cawan petri yang telah diberi aquades, kemudian lembaran insang diletakkan diobejck glass dilakuan pencacahan yang selanjutnya diamati di bawah mikroskop binokuler. Sedangkan untuk pemeriksaan ektoparasit pada bagian sirip dilakukan dengan memotong sirip menggunakan gunting, kemudian diletakkan pada object glass, untuk selanjutnya diamati dengan cara menggunakan mikroskop binokuler. Kemudian Prevalensi $=\frac{\text { Jumlah ikan sampel yang terserang }}{\text { Jumlah ikan sampel yang diperiksa }} \times 100 \%$ Intensitas $\quad=\frac{\text { Jumlah ektoparasit } \mathrm{A} \text { yang menginfeksi }}{\text { Jumlah ikan sampel yang terserang ektoparasit A }}$ Dominansi $=\frac{\text { Jumlah satu jenis ektoparasit yang menginfeksi ikan sampel }}{\text { Jumlah total ektoparasit yang menginfeksi ikan sampel }} \times 100 \%$

\section{Pemeriksaan Parameter Kualitas Air}

Pemeriksaan suhu dilakukan in situ dengan menggunakan termometer air raksa, dilakukan pada beberapa titik pengamatan. Termometer itu dicelupkan secara langsung kedalam media air waduk selama kurang lebih satu menit, kemudian dilakukan pencatatan suhu berdasarkan angka pengamatan pada termometer tersebut.

Pengamatan $\mathrm{pH}$ menggunakan kertas indikator dengan kisaran nilai $\mathrm{pH}$ dari $1-$ 
14. Tahapan pelaksanaan pengukuran $\mathrm{pH}$ yang diawali dengan mencelupkan beberapa kertas indikator pada beberapa titik media pengamatan, selanjutnya perubahan warna pada kertas indikator tersebut distandarkan dengan warna apada kotak indikator $\mathrm{pH}$.

Pengamatan nilai oksigen terlarut/ dissolved oksigen/DO pada prinsipnya menggunakan metoda winkler, walaupun pada saat pelaksanaan menggunakan test kit untuk pembanding. Adapun metode titrasi dengan cara Winkler secara umum banyak digunakan untuk menentukan kadar oksigen terlarut. Pada prinsipnya dengan menggunakan titrasi iodometri. Sampel air yang akan dianalisis, terlebih dahulu ditambahkan larutan $\mathrm{MnCl}_{2}$ dan $\mathrm{NaOH}$ atau $\mathrm{KI}$, sehingga akan terkjadi endapan $\mathrm{MnO}_{2}$. Dengan menambahkan $\mathrm{H}_{2} \mathrm{SO}_{4}$ atau $\mathrm{HCl}$ maka endapan yang terjadi akan larut kembali dan juga akan membebaskan molekul Iodium $\left(\mathrm{I}_{2}\right)$ yang ekivalen dengan kandungan oksigen terlarut dalam air contoh. Iodium yang dibebaskan ini selanjutnya akan dititrasi dengan larutan standar natrium tiosulfat $\left(\mathrm{Na}_{2} \mathrm{~S}_{2} \mathrm{O}_{3}\right)$ dan menggunakan larutan amilium sebagai indikator.

Pengamatan nilai amoniak atau $\mathrm{NH}_{3}$ pada prinsipnya juga menggunakan metoda spektrofotometer. Metode spektrofotometer dilakukan berdasarkan absorban nilai tampakan oleh suatu larutan berwarna. Oleh karena itu metoda ini dikenal juga sebagai metoda kalorimeter. Kalorimeter adalah metode yang membandingkan jumlah cahaya yang diserap pada larutan standar dengan cahaya larutan sampel di tabung Nessler.

Tabel 1. Jenis, pravalensi, intensitas dan dominasi ektoparasit di perairan Waduk Darma

\begin{tabular}{clcrc}
\hline No. & \multicolumn{1}{c}{ Jenis parasit } & Prevalensi & Intensitas & Dominansi \\
\hline 1 & Trichodina sp. & 66,67 & 131,50 & 12,77 \\
2 & Argulus sp. & 26,67 & 1 & 0,04 \\
3 & Epistylis sp. & 66,67 & 715,40 & 69,49 \\
4 & Vortic ella sp. & 26,67 & 61,25 & 2,38 \\
5 & Ichthyophthirius multifilis & 60 & 62 & 5,42 \\
6 & Diplozoon sp. & 20 & 2 & 0,06 \\
7 & Dactylogyrus sp. & 100 & 51,67 & 7,53 \\
8 & Cichlidogyrus sp. & 40 & 25,33 & 1,48 \\
9 & Gyrodactylus sp. & 66,67 & 8 & 0,78 \\
10 & Heterobothrium sp. & 20 & 2 & 0,06 \\
\hline
\end{tabular}




\section{HASIL DAN PEMBAHASAN}

Hasil pengamatan dari kegiatan

penelitian ini dapat dilihat pada Tabel

1. Berdasarkan Tabel 1 diatas

dapat diketahui bahwa

terdapat tiga jenis parasit yang

memiliki nilai prevalensi yang

sama yaitu sebesar

66,67: Trichodina sp.,

Epistylis sp., serta

Gyrodactylus sp. Nilai

prevalensi tertinggi

dicapai oleh parasit

Dactylogyrus sp, namun dominansi parasit $(7,53)$ ini tidak mencapai nilai tertinggi. Adapun nilai dominansi dan intensitas tertinggi diperoleh parasit Epistylis sp. dengan nilai sebesar 69,49 dan 715,40. Terdapat hasil yang menarik dari penelitian ini (Tabel 1), dimana lima jenis parasit dari total 10 parasit yang ditemukan adalah dari golongan Monogenea: Cichlidogyrus sp. (lihat Gambar 2), Gyrodactylus sp., Heterobothrium sp., Diplozoon sp., serta Dactylogyrus sp. (lihat Gambar 3).

Gambar 2. Tampilan ektoparasit Cichlidogyrus sp. perbesaran 100 dari perairan Waduk Darma Kabupaten Kuningan, Provinsi Jawa Barat 
Chichlidogyrus sp. termasuk dalam golongan monogenea, parasit ini mengeluarkan telur dan setelah menetas akan menjadi larva berenang bebas yang disebut oncomiracidia dan menginfeksi inang dalam beberapa jam. Setelah mencapai inang parasit ini bermigrasi ke target organ dan berkembang menjadi parasit dewasa. Salah satu genus dalam golongan monogenea yang tidak mengeluarkan telur adalah Gyrodactylus. Parasit ini mengeluarkan larva dari uterus parasit (viviparus) dan menginfeksi inang melalui kontak fisik (Anshary, 2008 dalam Marlan \& Sri, 2014). Selain itu, Salgado \& Rubio 2014 dalam Fey et al. (2015) menyatakan bahwa ektoparasit $C$. sclerosus and Gyrodactylus cichlidarum ditemukan menyerang ikan nila.

Kulit ikan sesungguhnya memiliki sistem pertahanan untuk menangkal serangan mikroorganisme dari luar tubuh melalui adanya mukus/selaput lendir.

$$
\text { Sistem pertahanan yang }
$$
demikian ternyata mampu ditembus oleh ektoparasit. Karena ektoparasit memiliki enzim dari golongan Cystein protease, pada ektoparasit Lepeophtheirus salmonis merupakan jenis Cathepsin L protease (Mc Carthy et al., 2012) yang mirip dengan enzim papain yang mampu menghancurkan mukus selaput lendir serta melunakkan otot ikan sehingga dengan mudah anchor dari ektoparasit masuk dan mencengkram otot. Inilah disebut infeksi/luka yang disebabkan ektoparasit. Dampak pertama yang akan terjadi ketika ektoparasit menempel pada inangnya adalah penghisapan darah atau cairan tubuh inang. Malhaeros et al. (2016) menyatakan bahwa organ target infeksi parasit golongan Monogenea dainataranya adalah insang. 
Gambar 3. Tampilan ektoparasit Gyrodactylus sp. perbesaran 100 dari perairan Waduk Darma Kabupaten Kuningan, Provinsi Jawa Barat

Ketika itu terjadi maka pasti akan terjadi perubahan kandungan beberapa parameter darah, seperti haemoglobin dan hematokrit (Gonzales et al., 2016). Hashimoto et al (2016) menyatakan bahwa infeksi Monogenea menyebabkan perubahan gambaran hematologi atau gambaran darah pada ikan.

Tiga parasit berikutnya yang ditemukan di perairan waduk Darma adalah Heterobothrium sp., Diplozoon sp. serta parasit Dactylogyrus sp. Pada umumnya cara serangan ektoparasit ini adalah dengan menancapkan jangkar pada bagian tubuh inang yang diinfeksi, sehingga dapat menyerap darah dari pembuluh kapiler. Dalam jumlah yang sangat banyak, serangan ektoparasit ini dapat menimbulkan kematian, bagi dari infeksi primer yang ditimbulkannya

maupun infeksi sekinder yang kemudian akan menjadi pintu pembuka bagi masuknya agen patogen yang lain. Menurut Juwaihir et al. (2016) Dactylogyrus extensus umumnya ditemukan di insang baik pada ikan liar maupun ikan yang dibudidayakan, dan hanya $6,7 \%$ species tersebut ditemukan menginfeksi kulit. Dactylogyrus sp. dari perairan Waduk Darma, seperti terlihat pada Gambar 4., bila menyerang insang dalam jumlah yang banyak dapat menyebabkan kematian, karena insang pengeluaran lendir yang 
terlalu banyak dari insang, sehingga insang mengalami iritasi. Selain itu, Dactylogyrus sp., juga dapat menghisap darah dari pembuluh kapiler insang. Kondisi ini dapat melemahkan ikan sehingga dapat mengakibatkan kematian.

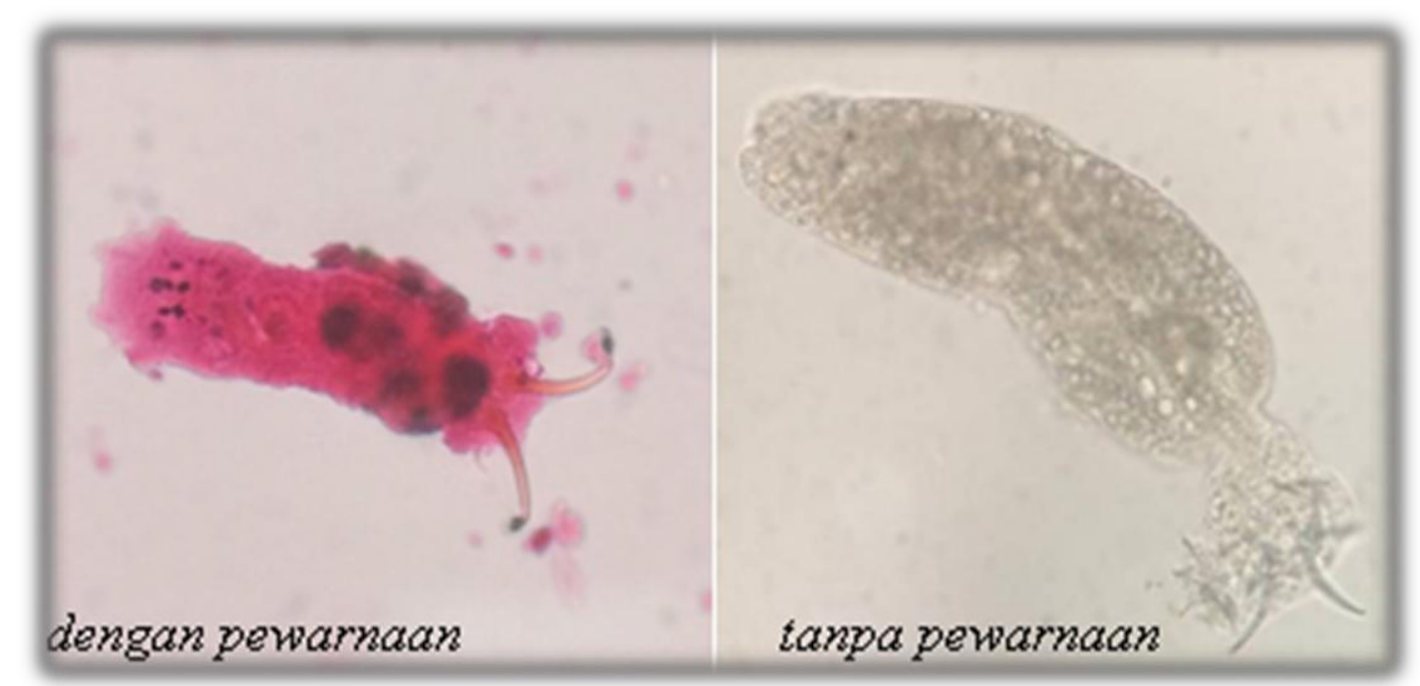

Gambar 4. Tampilan ektoparasit Dactylogyrus sp. perbesaran 400 (berwarna \& tidak berwarna) dari perairanWaduk Darma Kabupaten Kuningan, Provinsi Jawa Barat

$\begin{array}{rrrr}\text { Chao } & \text { et al. } & \text { (2014) } \\ \text { mengatakan } & \text { bahwa } & \text { genus }\end{array}$ Dactylogyrus meliputi lebih dari 900 spesies Monogenea jenis ini merupakan parasit insang yang paing banyak ditemukan pada ikan air tawar, diantaranya dari golongan cyprinid. Parasit Dactylogyrus sp. menyebabkan infeksi yang serius pada filamen insang, sehingga akan mengganggu proses respirasi (Chaudary et al, 2017, serta Iqbal \& Fauzia, 2014).

Variasi musim yang secara langsung juga akan mempengaruhi temperatur atau suhu wilayah perairan, merupakan faktor abiotik yang paling mempengaruhi kelimpahan ektoparasit golongan Monogenea. Variabel suhu secara umum berimbas pada kondisi fisiologi dari Monogenea dalam hal produksi dan tingkat penetasan telur, pertumbuhan serta juga perkembangan Monogenea, walaupun dilihat dari sisi lain, kenaikan suhu akan memperpendek jangka usia dari Genus ini (Fey et al., 2015). Parasit Cichlidogyrus sclerosus, Cichlidogyrus dossoui dan Scutogyrus sp. merupakan contoh Monogenea yang menginfeksi insang ikan Nila. Selain itu, 
parasit-parasit tersebut, Diplozoon kashmirensis termasuk Monogenea yangditemukan menyerang insang ikan mas ( Gambar 6).

$$
\text { Panjvini et al., (2016) }
$$

menyatakan bahwa serangan ektoparasit juga akan menimbulkan berbagai gangguan alam tubuh ikan, diantaranya dalam hal gambaran darah seperti turunnya nilai hematokrit dan hemoglobin, histologi, serta penurunan pertumbuhan. Diplozon sp. (Gambar 6.) dan Heterobothrium $\mathrm{sp}$ (Gambar 7.) termasuk pada golongan ektoparasit, sehingga keduanya diduga juga akan menimbulkan kerugian bagi inang yang diinfeksinya.

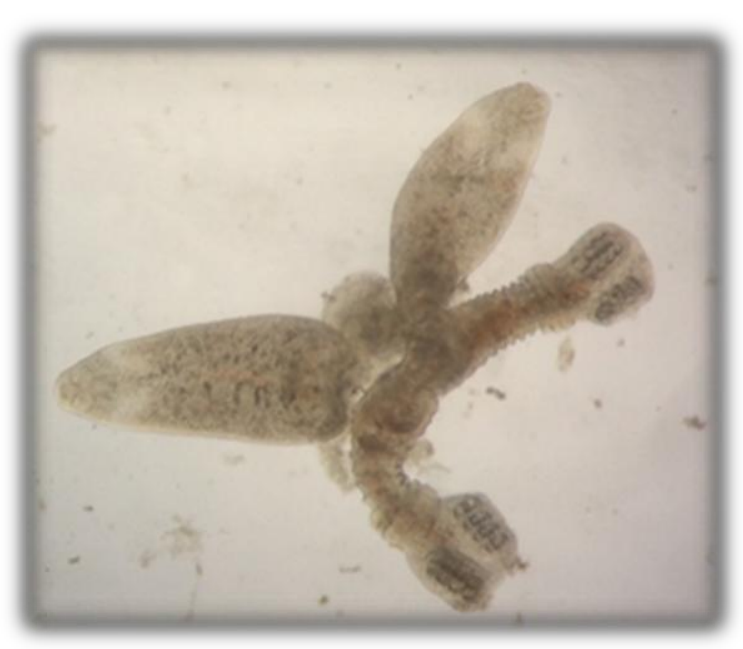

Gambar 6. Tampilan ektoparasit Diplozoon sp. perbesaran 100 dari perairan Waduk Darma Kabupaten Kuningan, Provinsi Jawa Barat 


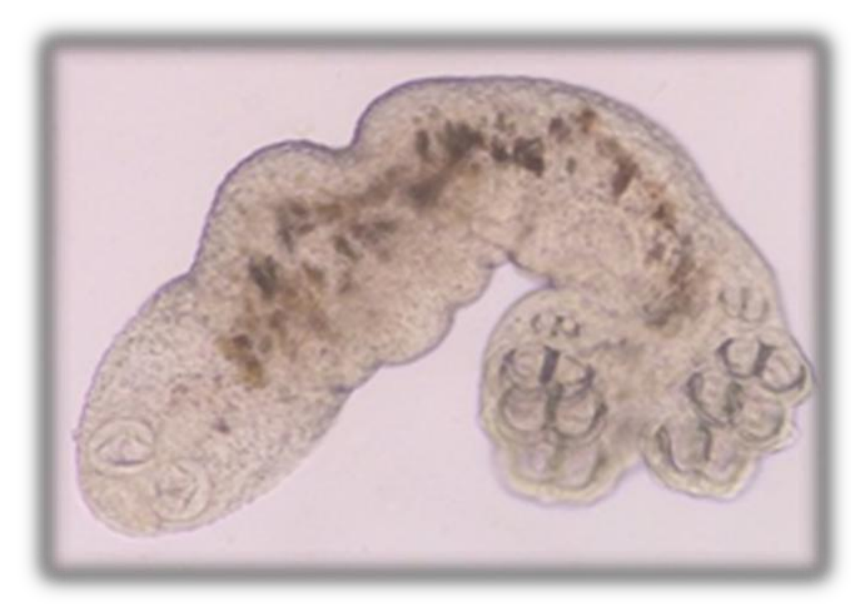

Gambar 7. Tampilan ektoparasit Heterobothrium sp. perbesaran 100 dari perairan Waduk Darma Kabupaten Kuningan, Provinsi Jawa Barat

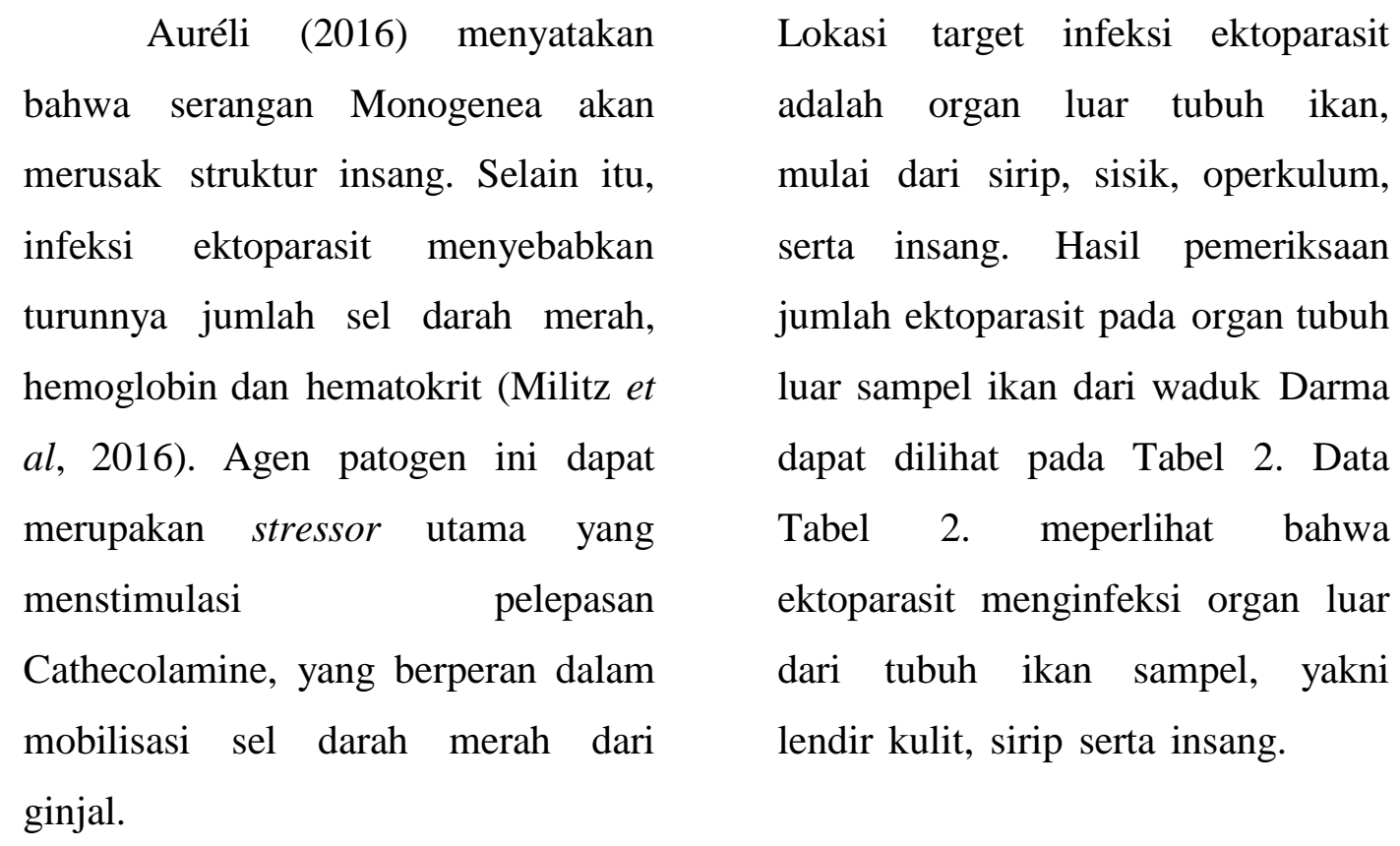


Tabel 2. Jumlah Ektoparasit pada sampel Ikan Mas (Cyprinus carpio) dari perairan Waduk Darma Kabupaten Kuningan, Provinsi Jawa Barat

\begin{tabular}{clccc}
\hline \multirow{2}{*}{ No. Jenis parasit } & \multicolumn{3}{c}{ Jumlah Parasit pada: } \\
\cline { 2 - 5 } & & Lendir Kulit & Sirip & Insang \\
\hline 1. & Trichodina sp. & 254 & 60 & 1 \\
2. Argulus sp. & 4185 & 2637 & 332 \\
3. & Epistylis sp. & 245 & - & - \\
4. & Vorticella sp. & 140 & 62 & 356 \\
5. Ichthyophthirius multifilis & - & - & 6 \\
6. Diplozoon sp. & - & - & 775 \\
7. & Dactylogyrus sp. & - & - & 152 \\
8. Cichlidogyrus sp. & 27 & 51 & 2 \\
9. Gyrodactylus sp. & - & - & 6 \\
10. & Heterobothrium sp. & & & \\
\hline
\end{tabular}

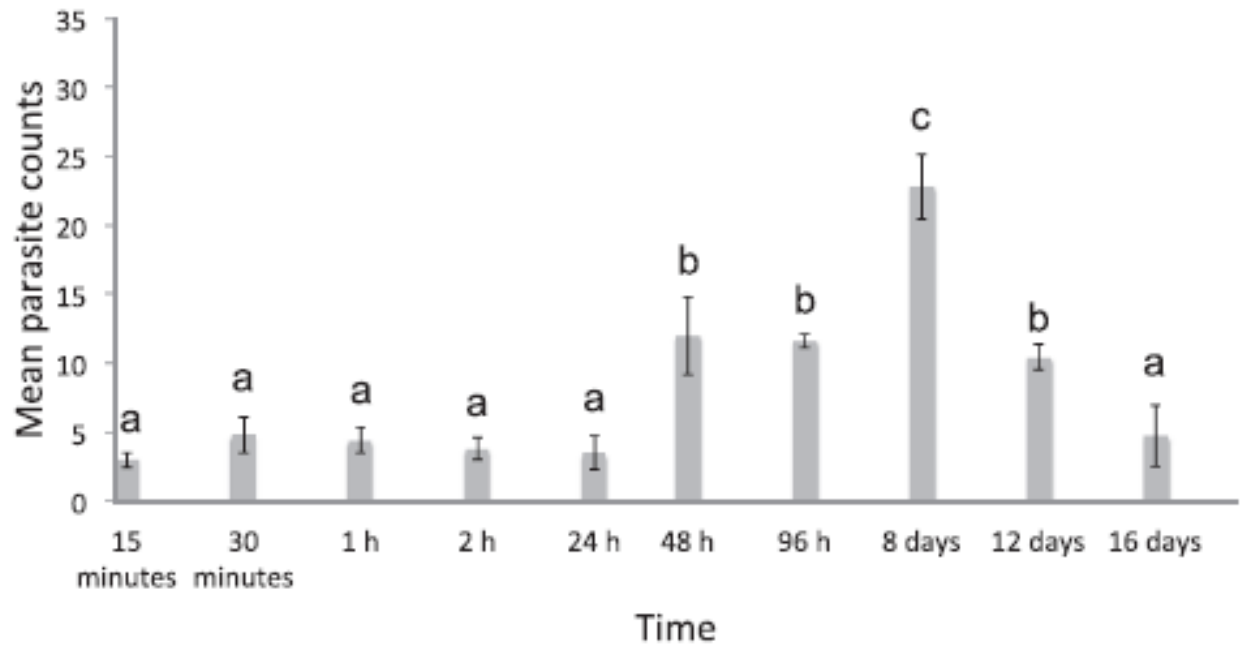

Gambar 8. Jumlah rata-rata ektoparsit Neobenedenia sp. yang menginfeksi sampel ikan kakap (Lates calcarifer) pada kepala (A), badan (B) dan sirip (C); ditentukan dengan menggunakan tes HSD Tukey (sumber Gonzal et al., 2015)

Terdapat empat jenis ektoparasit pada sampel ikan ini yang hanya ditemukan pada bagian insang, yaitu ektoparasit Diplozoon sp., Dactylogyrus sp., Cichlidogyrus sp. serta Heterobothrium sp. dengan jumlah parasit (individu) yang ditemukan adalah: 6, 775, 152 serta 6. Menurut Sobrinhoa \& Marcos (2016) yang menyatakan bahwa jenis parasit yang menginfeksi tidak tergantung pada ukuran inang atau ikan Diversitas atau keragaman parasit dipengaruhi oleh beberapa 
parameter kualitas air (Gaikwad et al, 2016). Untuk lokasi infeski ektoparasit, hal ini sesuai dengan pendapat Gonzales et al(2015) yang diperlihatkan pada Gambar 8.

\section{KESIMPULAN}

Terdapat tiga jenis

parasit di perairan Waduk Darma

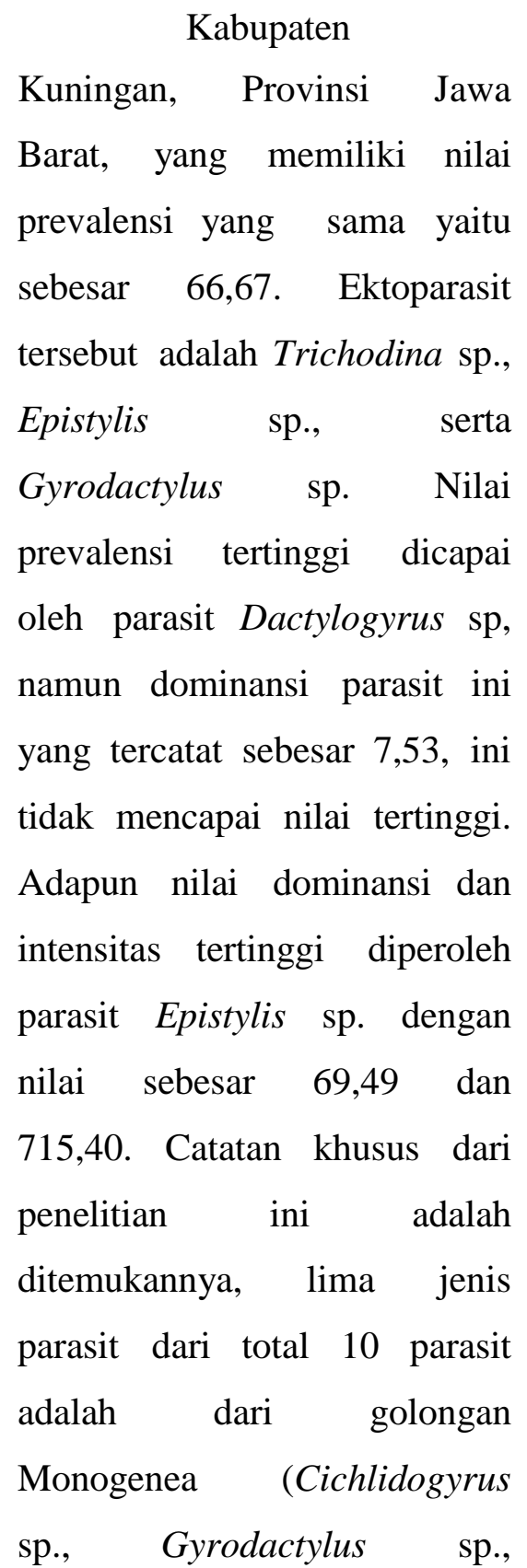

Heterobothrium sp., Diplozoon sp., serta Dactylogyrus sp.).

\section{PERSANTUNAN}

Ucapan terimakasih disampaikan kepada Ketua Jurusan Penyuluhan Perikanan, Sekolah Tinggi Perikanan, yang telah memfasilitasi pendanaan penelitian ini,; yang telah memfasilitasi bantuan peralatan dan tenaga lapangan, selama penelitian, semua petugas Laboratorium Kesehatan Ikan, pada Departemen Akuakultur, Fakultas Perikanan dan Ilmu Kelautan, Institut Pertanian Bogor yang menangani identifikasi parasit. Petugas pada Laboratorium Kesehatan Ikan, Departemen Akuakultur, IPB

\section{DAFTAR PUSTAKA}

AlejandroTrujillo-Gonzalez., Constantin, Constantinoiu b, Richard Rowe, Kate S Hutson. 2015. Tracking Transparent Monogenean Parasites on Fish from Infection toMaturity. International. In a Journal for Parasitology: Parasites and Wildlife 4. 316e 322

Aurélia Saraiva, Joana Costa, Joana Serrão, Jorge C Eiras, Cristina Cruz. 2016. Study of the gill health status of farmed sea bass (Dicentrarchus labrax L., 1758) using different tools. Journal of Aquaculture 441: 16-20. 
Chao Jiang, Zhuo-QiWu, Lei Liu, Guang-Lu Liu, Gao-Xu Wang. 2014. Synergy of herbal ingredients combination against Dactylogyrus spp. In an infected goldfish model for monogenean management. Short communica tion. Aquaculture 433: 115-118.

Chaudhary Anshu, Haren Ram Chiary, Hridaya Shanker Singh. 2017. First molecular confirmation of the

$\begin{array}{rr}\text { Dactylogyrus } & \text { anchoratus } \\ \text { and } \quad D . & \text { vastator- }\end{array}$ (Monogenea, Dactylogy ridae) from Carassius auratus in western India. Research Article. Bio Invasions Records (2017) Volume 6, Issue 1: 79-85

Fey Daniel Aguirre, Grecia E Ben'itez- Villa, Gerardo P'erez-Ponce de Le'on, Miguel Rubio-Godoy. 2015. Population dynamics of Cichlidogyrus spp. and Scutogyrus sp. (Monogenea) infecting farmed tilapia in Veracruz at Mexico. Aquaculture 03004.

Gaikwad JM, Deshmukh, Shaziya Sultana KA. 2016. Diversity of Fish Parasites in Relation to Water Quality of Reservoir from Parbhani District. Research Journey' International Multidiscip linary EResearch Journal Special Issue 4 - Recent Advances \& Opportunities in Animal Sciences Impact Factor. 21 $-26 \mathrm{p}$
Gonzalez Alejandro Trujillo, Constantin C Constantinoiu, Richard Rowe, Kate S Hutson. 2015. Tracking transparent monogenean parasites on fish from infection to Maturity. International Journal for Parasitology: Parasites and Wildlife 4. 316e322.

González MP, JLP Muñoz, V Valerio and LV Chacoff. 2016. Short Communication: Effects of the ectoparasite Caligus rogercresseyi on Salmo salar blood parameters under farm conditions . Aquaculture, 457: 2934.

Hamzah Jawadhira Abdulhusein, Mohamed Fawzy Abdulkarim, Marwa Khaled. 2017. Diagnosis of Parasitic Diseases of Fish Cages (Cyprinus carpio) in the A; Furat River Bridge of Mussayab in Babylon Province. Journal for Veterinary Medical Sciences Vol. 8 (1).

Hashimoto, Gabriela Sayuri de Oliveira, Fausto Marinho Neto, Maria Luiza Ruiz, Monyele Acchile, Edsandra Campos Chagas, Francisco Célio Maia Chaves, Maurício Laterça Martins. 2016. Essential oils of Lippia sidoides and Mentha piperita against monogenean parasites and their influence on the hematology of Nile tilapia. Aquaculture 450: 182186

Iqbal Zafar, Fauzia Haroon. 2014. Parasitic Infections of Some Freshwater Ornamental Fishes Imported in Pakistan. Pakistan $J$. Zool., vol. 46(3), pp. 651-656.

Ismail, Arif., Eko Kuratmoko., Sobirin. 2015. Permodelan Perubahan Penggunaan Lahan dan 
Pengaruhnya terhadap Koefisien Aliran pada Daerah Tangkap Air Waduk Darma, Kabupaten Kuningan, Propinsi Jawa Barat. Jurnal Ilmu Kehutanan, Wanakarsa, Vol 9 (2) 2015, ISSN 02160733 pada Fakultas Kehutanan Universitas Kuningan

Juwaihir Andi, Zakirah Raihani Ya'la, Rusaini. 2016. Prevalensi dan Intensitas Ektoparasit pada Ikan Mas (Cyprinus carpio L.) di Kabupaten Sigi. Journal Agrisains 17 (2): 68 - 75

Kabata Z. 1985. Parasites and Diseases of Fish Cultured in The Tropics. Publisher: Taylor dan Francis. Ltd. UK. 318 p

Malheiros Dayna Filocreão, Patrícia, Oliveira Maciel, Marcela, Nunes Videira, Marcos Tavares-Dias. 2016. Toxicity of the essential oil of Mentha piperita in Arapaima gigas(pirarucu) and antiparasitic effects on Dawestrema spp. (Monogenea). Aquaculture 455:

$81-86$

Marlan, Sri Sukari Agustina. 2014. Analisis Prevalensi Parasit Yang menginfeksi Benih Ikan Nila (Oreochromis niloticus) Pada Sentra Pembenihan di Wilayah Kabupaten Banggal. Jurnal Balik Diwa. Volume 5 (2): 40-48.

Mc Carthy E, Cunningham, L Copley, D Jackson, D Johnston, JP Dalton and G Mulcahy (2012). Cathepsin L proteases of the parasitic copepod, Lepeophtheirus salmonis. Aquaculture (356-357): 264-271.

Militz, Thane A., Paul C Southgate., Alexander G Carton, Kate S Hutson. 2013. Dietary supplementa tion of garlic (Allium sativum) to prevent monogenean infection in aquaculture. Aquaculture 408-409: 95-99

Panjvini Faraz, Safoura Abarghuei, Hossein Khara, Hossein Mohammadi Parashko. 2016. Parasitic infection alters haematology and immunity parameters of common carp, Cyprinus carpio, Linnaeus, 1758. Journal Parasit Dis.

Sobrinhoa Aristides Ferreira, Marcos Tavares-Dias. 2016. A study on monogenean parasites from the gills of some cichlids (Pisces: Cichlidae) from the Brazilian Amazon. Revista Mexicana de Biodiversidad 87. 10022009 